JMKSP (Jurnal Manajemen, Kepemimpinan, dan Supervisi Pendidikan)

Volume 7 Issue 1 (2022) Page 53-66

ISSN 2614-8021 (Online) 2548-7094 (Print)

\title{
Improving Learning Outcomes of Human Circulatory System Materials with Picture and Picture
}

\author{
Raitan Dewi ${ }^{1}$, Saleh Hidayat ${ }^{2}$, Astrid S. W. Sumah ${ }^{2}$ \\ ${ }^{1}$ SMP Negeri 3 Teluk Gelam ${ }^{2}$ Universitas Muhammadiyah Palembang \\ Corresponding Author E-mail: raitan_dewi@yahoo.com
}

Received 2 Augut 2021; Revised 1 September 2021; Accepted 3 January 2022

\begin{abstract}
The goal of this study was to see if there was an improvement in student learning outcomes in the areas of knowledge, attitudes, and abilities in the scientific subject matter of the Human Circulatory System using the Picture and Picture learning methodology for class VIII students at SMP Negeri 3 Teluk Gelam. CAR is a sort of study that is conducted in two cycles. Students from class VIII of SMP Negeri 3 Teluk Gelam participated in the study. Techniques for gathering data include both test and non-test methods. The findings revealed an increase in scientific learning outcomes for the human circulatory system content between cycles I and II.
\end{abstract}

Keyword: Learning Achievement, Picture and Picture, Human Circulatory System Material

\section{Introduction}

Learning outcomes are a process of modifying a student's knowledge abilities, attitude abilities, and skill abilities based on their level of mental and spiritual growth, which may be used to determine a student's level of success in mastering the subject matter. The level of attainment of competence targets from a sequence of learning process stages can be stated numerically. According to Mulyasa (2013), the evaluation of student learning outcomes in the 2013 curriculum must encompass components of knowledge, attitudes, and abilities in a 
proportionate and intact manner, in accordance with the identified core competencies. In the 2013 curriculum, the teacher's role in measuring student learning objectives is as a facilitator, moderator, and assessor, encouraging students to think, communicate, and educate students' democracy in respecting the viewpoints of others.

Because the differences in the features of each topic in science subjects generate changes in the manner it is presented, from the total subject matter that is expected in a curriculum that is attained by educators, an educator must have comprehensive knowledge when selecting a learning model. since not all subjects suit a learning model, but certain topics fit another learning model, such as the Human Circulatory System in class VIII Semester II.

Students must understand the Human Circulatory System in depth since it comprises a pretty extensive subject matter encompassing the basic ideas of circulatory organs, kinds of blood circulation, and circulatory system disorders/diseases. blood of a person Because this subject is a required content for the subsequent courses, such as the Respiratory System, students are expected to have a good knowledge. Teachers should always strive to discover the best manner to communicate the material. Using a range of creative and unique learning approaches, such as small group discussions and questions and answers, is one of the things that may be done.

According to the researcher's observations as a teacher at SMP Negeri 3 Teluk Gelam, issues during teaching and learning activities in scientific topics frequently discovered numerous problems such as: 1) There was a lack of student order during the learning process; 2) Student learning outcomes related to the Human Circulatory System did not achieve the standard criteria. The results of student assessments in the second semester of the 2018/2019 academic year show that 30.34 percent of students fulfilled their learning outcomes, while 69.66 percent did not (Archive: Subject Teacher of SMP Negeri 3 Teluk Gelam 2018/2019). This accomplishment remains considerably below the school KKM of $70 \%$; 3) Inadequate availability of learning material.

Because the author is a teacher at SMP Negeri 3 Teluk Gelam, the essential data will be easy to collect, and the instructor also requires creativity in 
the learning process in his own class. The Picture and Picture learning paradigm, according to Hamdani (2011), is a learning approach that use pictures as media. During the application process, the photographs will be matched together or sorted into a more logical sequence. The advantage of this Picture and Picture learning style is that it makes it simpler for students to grasp what the instructor is conveying; as a result, pupils are fast to respond and understand the subject matter offered since it is accompanied by visuals (Shoimin, 2014).

According to Trianto (2010) the processes of the picture and picture learning model 1) The instructor communicates the competences or learning objectives to be attained during the course of the learning activities. 2) As an introduction, the teacher begins the session by giving the information. 3) The teacher displays pictures related to the subject matter to be delivered; 4) The teacher calls the students by having them take turns installing and sorting the pictures so that they form pairs or logical sequences; 5) The teacher asks questions about the students' reasons for the order of pictures. Following a review of the image, the instructor begins to link with the notion of the subject matter to be studied in accordance with the competency objectives to be met; 6) Conclusion.

The following are the main concepts of Picture and Picture Learning, as stated by Suroyya (2018) 1) All group work is the responsibility of each group member. 2) All group members must be aware that they all share the same purpose. 3) Each group member's duties and responsibilities must be the same; 4) Each group member will be evaluated; 5) Each group member shares responsibilities and demands a skill ability throughout the joint learning process activities; 6) Each group member will be asked to respond individually to the content addressed in his or her group.

According to Budiyanto (2016), the advantages of the Picture and Picture learning paradigm are as follows: 1) Educators can better grasp the talents held by each of the pupils; 2) Teach pupils how to think more rationally. 3) Can assist students in becoming used to learning by processing thought patterns based on linguistic subjects while yet allowing students flexibility in thinking activities; 4) The instructor builds incentive for each student to study better. 5) Students are 
involved in the planning and implementation of classroom management strategies. Meanwhile, the downsides of the Picture and Picture learning paradigm are as follows: 1) it takes longer; 2) many pupils are likely to be idle or inert; 3) Vulnerable to classroom disorder or disturbance; 4) Many kids will be unhappy if they are required to work in groups with other students; 5) Adequate facilities, tools, and prices are desperately needed.

Gaffar (2018) conducted this study titled "Application of the Picture And Picture Cooperative Learning Model to Improve Junior High School Student Learning Outcomes in Science Learning," which demonstrated that using the Picture and Picture learning model in the science learning process can improve a student's learning outcomes. student. From the pre-cycle to the second cycle, there is an increase in the accomplishment value of student learning outcomes. The class's average value in the pre-cycle is 57.5, and the acquisition of classical completeness is $35 \%$. According to research on the process of learning activities in the first cycle, the average acquisition value of pupils is 72 , while traditional completeness acquisition is 55 percent. According to research on the process of learning activities in cycle II, the average score of pupils is 79.8, while classical completeness acquisition is 77.5 percent. According to the findings of this study, adopting the Picture and Picture learning approach can improve student learning results. However, this research differs from past research in that it is concerned with efforts to enhance student learning outcomes on the subject of the human circulatory system using the Picture and Picture learning model and the Class Action Research method. Previous study and the researchers' research were comparable in that they both evaluated the Picture and Picture learning paradigm and learning results. While the researcher differs from past studies in that she does not assess learning implementation and motivation, she does examine whether there is an improvement in learning outcomes in the cognitive, emotional, and psychomotor domains.

\section{Methods}

This study was conducted at SMP Negeri 3 Teluk Gelam employing Classroom Action Research in two cycles, namely cycle I and cycle II. The 
subjects of this study were 27 students from class VIII of SMP Negeri 3 Teluk Gelam, 19 of them were female and 8 of whom were male. The research was conducted in February 2020, during the even semester of the 2019/2020 school year. This study collected quantitative and qualitative data in the form of outcomes of students' cognitive, emotional, and psychomotor skills. The data was collected using multiple choice and non-testing approaches.

\section{Results and Discussion}

Students' Cognitive

Based on the results of the written test for class VIII SMP Negeri 3 Teluk Gelam on the science learning of the human circulatory system using the Picture and Picture learning methodology, it can be shown that student learning outcomes improved in cycles I and II. In the first cycle, there were 12 students who completed the category and 15 students who completed the incomplete category. While the results of the written test in the second cycle showed that 23 students achieved the entire category and 4 students achieved the incomplete category. Furthermore, when compared to the first cycle, the average score is 62.40 , which is 44 percent complete, and the average score in the second cycle is 80 , which is 85 percent complete.

This is consistent with the statement made by Ariana et al (2019) that using the Picture and Picture learning model can increase student motivation and achievement of learning outcomes because students are already familiar with the model used during learning and students become more understanding and can visualize the subject matter with the pictures that have been shared. 


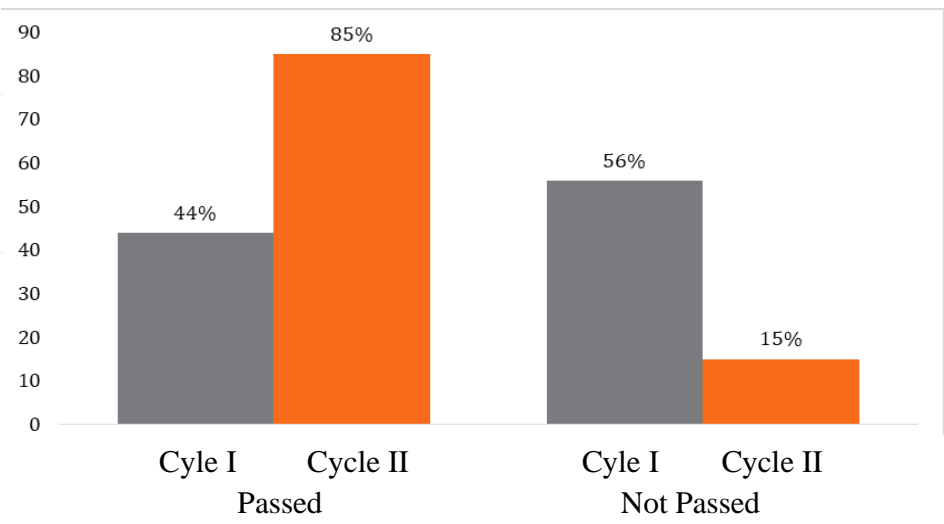

Figure 1. Percentage of Cognitive in Cycle I and Cycle II

\section{Students' Affective}

There was an increase based on the findings of the monitoring of attitudes from cycles I and II. According to the findings of the first cycle of attitude observation, 70.40 percent of the attitudes of students who were able to work together were grouped in issue solving. Students who appreciate the ideas of others have a 66.40 percent attitude. Meanwhile, pupils' attitudes that can create a high level of curiosity about the subject matter offered by the teacher receive a score of 67.20 percent. Furthermore, students' accountability in completing individual and group work received a score of 64.80 percent. Meanwhile, 59.20 percent of pupils responded directly or indirectly to questions presented by professors or peers. According to the average value of the class, which is 65.60. The attitude can not be said to have reached the indicators of success, because it is still in the lack of criteria.

In the second cycle, the results of observing the attitudes of students who were able to work together in groups to solve issues were 96\%. Students who appreciate others have a 93.6 percent attitude. While the attitude of being curious received 88.8 percent. Students score 84.8 percent on the attitude of responsibility. The proportion of attitudes in responding to questions provided by professors or friends is 86.4 percent. Based on the observations, it is also clear that 19 students have attitudes that fall into the very good category, while 8 
students have attitudes that fall into the good group. Furthermore, the class average score is 86.37 . This signifies that the findings of the attitude observation were able to meet the target success indication by getting extremely excellent criteria.

According to Paramita's (2019) research, exposing the Picture and Picture learning model can enhance students' attitudes owing to the care given to the process of learning activities. Thus, when the process of learning activities occurs, it can create a pleasant learning environment; students also appear enthusiastic about participating in learning, and are able to increase the sense of cooperation and enthusiasm of each group, so that students understand the material being studied more quickly.

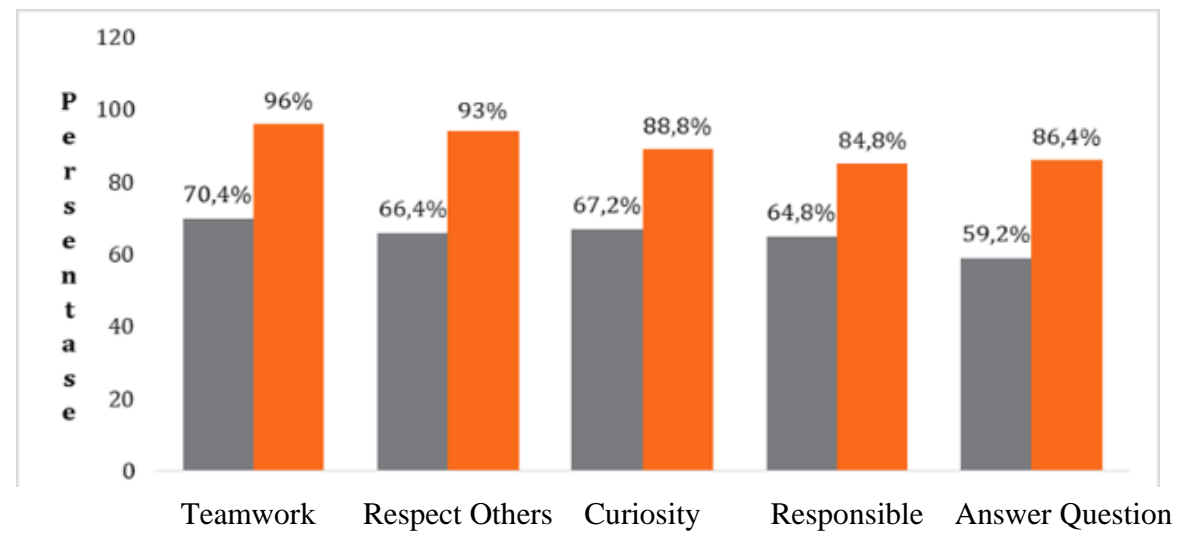

Figure 2. Percentage of Affective Observations in Cycle I and Cycle II

\section{Students' Psychomotor}

There was an increase based on the findings of the skill observations from cycles I and II. The findings of the first cycle's observation of student talents through working together in group discussions were 64\%. By 69 percent on the competence of pupils' talents in explaining to their friends. Cohesiveness in group discussions is $66 \%$. While group conversations were active in 63 percent of cases. Students' ability to receive explanations from peers is $71 \%$. Meanwhile, the 
average score for the class is 66.73 . This signifies that the outcomes of the attitude observation meet the success markers with adequate criteria.

During the second cycle, it was discovered that the students' abilities to collaborate when discussing groups were 68.8 percent. By 76 percent on the competence of pupils' talents in explaining to their friends. The capacity to be coherent in group discussions is 74.4 percent. While 75.2 percent of students participated in group conversations, 71.2 percent of students were skilled at accepting explanations from peers. Furthermore, 9 pupils were found to be in the very good group, while 18 students were found to be in the good category. Furthermore, the class average score is 87.88 . This signifies that the findings of the attitude observation met the level of success indicators with extremely high requirements.

According to the findings of Prasetyo (2018)'s research, learning through the use of the Picture and Picture learning paradigm improves learning skills. Because the Picture and Picture learning model makes students more remember and excited about learning, they frequently ask questions and assist one another in problem solving, therefore the Picture and Picture learning model delivers even superior learning skills.

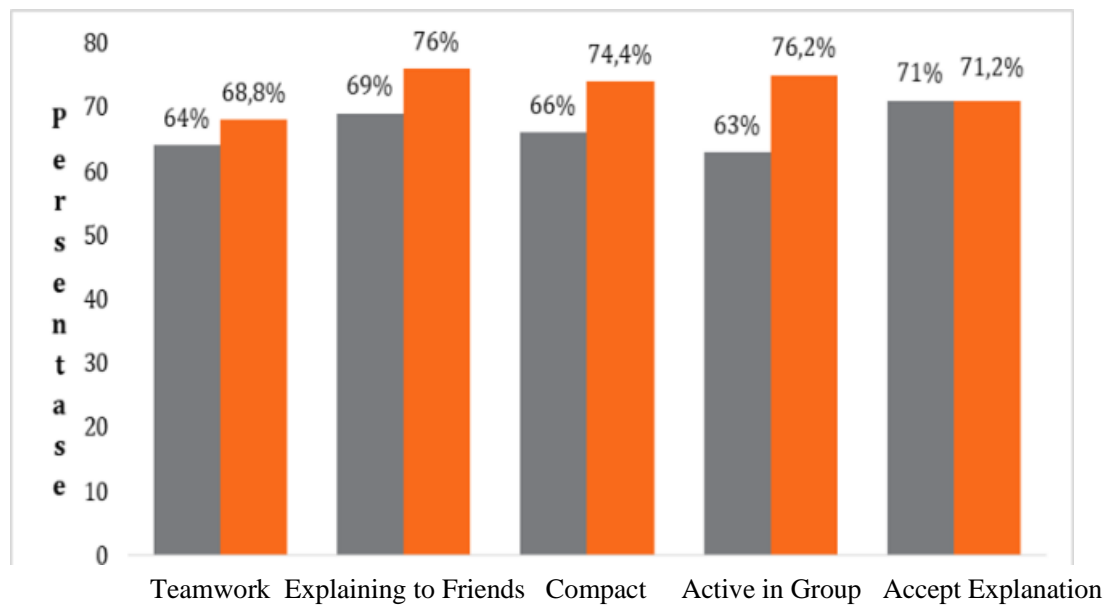

Figure 3. Percentage of Psychomotor Observation in Cycle I and Cycle II 
According to the findings in the field from the previously mentioned study review, there were various impediments or deficiencies throughout the teaching and learning process in the first cycle. These limits have a correlate or relationship to the learning outcomes gained by students, whether in terms of attitudes, abilities, or written exam scores, resulting in student learning outcomes that are nonetheless low and do not meet the standard requirements specified.

The following were the limitations of the first cycle: 1) The teacher's failure to provide directions and explanations during group discussions. This can be demonstrated by field findings: 1) There are still some students who refuse to be grouped with other students, making it difficult for these students to cooperate in the implementation of group discussions; and 2) Students have difficulty understanding the material presented by the educator. This is demonstrated by the fact that only a few students were able to answer the teacher's questions during the teaching and learning process, and it was discovered that several students achieved final test scores that were below the standard criteria, and 3) the teacher's inability to pique students' interest in learning. This can be seen from the students still walking around the class during the learning process, students going in and out of class and some students chatting with their friends when the teacher delivered the material.

Before the learning process begins, the instructor explains the names of the tools and functions, as well as how infocus works, so that students no longer feel uncomfortable with infocus and can participate in building a more conducive learning environment in order to reach a predetermined teaching objective. The teacher also goes through the Picture and Picture learning methodology that will be used in class. The same message was conveyed in the findings of Hamalik's (1986) research, which found that the use of media in learning during teaching and learning activities can foster students' curiosity and new interests, build student motivation, and provide stimulation or stimulus so that they can participate in learning activities, as well as have a positive psychological impact on students.

The usage of media aid in learning process activities is extremely beneficial in realizing the efficacy of the continuing learning process and making 
attempts to deliver messages and subject matter simpler. Furthermore, media in learning may increase students' skills, teachers can provide instructional materials in a highly fascinating and reliable method, and students are simpler to comprehend lessons and condense the knowledge received.

According to the findings of Elfira and Ghufron (2015), the usage of picture media must be tailored to the degree of student ability. Images that will be utilized as learning material should fulfill the following requirements: 1. Color images pique kids' interest since color is generally the first thing pupils see and then analyze; 2 . Images have a balanced size; 3 . The distance between things must be obvious; and 4. The image's movement is plainly evident.

Improvements to the teacher's lack of offering directions and explanations in group discussions, relating to the interpersonal relationship between students. Students struggle with self-concept knowledge and interpersonal skills. Researchers as instructors in this school develop a good sense of self-concept in kids, so that students can carry out social interactions properly in their surroundings, particularly with peers at school.

Subject teachers and BK teachers each play a role in this matter; it is suggested that they can improve the implementation of BK service activities such as orientation services, information services, group guidance and counseling on a regular basis with topics related to social interaction, providing content mastery services related to social interaction. with peers, and holding individual counseling activities if students require it.

According to Mayasari et al (2019), it is advised that students always endeavor to improve their knowledge, develop skills, and develop attitudes connected to social interaction itself, such as mutual trust, creating a sense of security, respect, collaboration, and so on. Improvements to the first cycle's weaknesses, including the teacher's inability to pique pupils' interest in learning, are as follows: Instructors improve relationships between teachers and students; collaborating in learning is essential. The teacher's approach to improving student learning in the classroom, which includes: 1) a power approach, 2) a threat approach, 3) a freedom approach, 4) a prescription approach, 5) a teaching method 
approach, 6) a behavior change approach, 7) a socioeconomic approach, and 8) a group work approach.

According to Djamarah (2010), attempts to capture attention and increase student learning motivation by implementing strong classroom management concepts, such as providing difficulties, developing media or different learning methods, building on positive things, and creating discipline, can present challenges. Good classroom management is a talent that the teacher must acquire in order to establish a more favorable classroom scenario and ambiance. Furthermore, the primary purpose of successful classroom management is to promote diverse learning activities in the social, intellectual, and emotional milieu of students in the classroom, resulting in a comfortable and enjoyable learning environment.

Based on the flaws that were discovered throughout the course of the learning activities in cycle I, the teacher and observers devised a plan for remedial action to be implemented in cycle II. At the start of the preparatory activity, the instructor clearly explains to students the educational objectives to be reached and the steps in the application of the Picture and Picture learning model. Furthermore, the instructor pays greater attention to students' preparedness to begin the lesson. Student readiness at the start is significant since it might make it simpler for students to accept and assimilate the subject matter offered by the teacher.

The outcomes improved after the teacher made modifications in cycle II, as indicated by an increase in student achievement of written exam scores. The teaching and learning process activities were carried out more effectively than in the previous cycle. Students appear organized and eager to learn throughout the preparatory exercises. When the teacher assigns discussion groups, the students demonstrate their interest, as seen by their positive responses. And pupils have begun to actively participate in group discussions.

Students participated actively in the group discussion process. When the instructor discussed the content, the pupils could be observed beginning to pay attention and listen to the teacher's presentation of the material. Them are able to 
perform it independently at the end of learning sessions, making it easier for students to grasp the content being studied.

Based on the activities from Cycle II, it was discovered that the adjustments in the learning process were more effective, comfortable, and enjoyable to students. As a consequence, while answering written test questions, pupils do well. Furthermore, it can be shown that pupils' attitudes and talents have improved.

\section{Conclusion}

According to the findings of research related to the application of the Picture and Picture learning model, there is an increase in the score of student learning outcomes in the domain of knowledge, attitudes, and skills in science subjects for the Human Circulatory System material using the Picture and Picture learning model in class VIII SMP Negeri 3 Teluk Gelam even semester TP 2019/2020.

\section{Acknowledgement}

We would like to express our special thanks and gratitude to the Principal SMP Negeri 3 Teluk Gelam and Rector of Muhammadiyah University of Palembang who gave us the support to do this project. This project was funded independent.

\section{References}

Ariana, K.M., Agustini, K., \& Sindu, I.G.P. (2019). Penerapan Model Pembelajaran Kooperatif Tipe Picture And Picture Untuk Meningkatkan Motivasi Dan Hasil Belajar Pada Mata Pelajaran TIK Di SMP Negeri 3 Seririt [Application of the Picture And Picture Cooperative Learning Model to Improve Motivation and Learning Outcomes in ICT Subjects at SMP Negeri 3 Seririt]. Jurnal Nasional Pendidikan Teknik Informatika, 8, 119128.

Budiyanto, A. K. (2016). Sintaks 45 Model Pembelajaran dalam Student Centered Learning [Syntax 45 Learning Models in Student Centered Learning]. 
Malang: UMMPress.

Djamarah, S. B. (2010). Strategi Belajar Mengajar [Teaching and Learning Strategy]. Jakarta: PT Rineka Cipta.

Elfira., \& Ghufron. (2015). Pengaruh Penggunaan Powerpoint terhadap minat dan hasil belajar IPA Kelas IV [The Influence of Using Powerpoint on Interest and Learning Outcomes in Science Class IV]. Jurnal Inovasi Teknologi Pendidikan, 2(1), 94-104 http://journal.uny.ac.id/index.php/jitp.

Gaffar, A. A. (2018). Penerapan Model Pembelajaran Kooperatif Tipe Picture And Picture Untuk Meningkatkan Hasil Belajar Siswa SMP Pada Pembelajaran IPA [The Application of the Picture And Picture Cooperative Learning Model to Improve Junior High School Students' Learning Outcomes in Science Learning]. Jurnal Bio Educatio, 3(1).

Hamalik, O. (1986). Media Pendidikan [Educational Media]. Bandung: Bumi Aksara.

Hamdani. (2011). Strategi Belajar Mengajar [Teaching and Learning Strategy]. Bandung: Pustaka Setia.

Mayasari, S. (2019). Penerapan Model Pembelajaran Kooperatif Tipe Picture And Picture untuk Meningkatkan Hasil Belajar IPS Siswa Kelas III SD Negeri 37 Pekanbaru [The Application of the Picture And Picture Cooperative Learning Model to Improve Social Studies Learning Outcomes for Class III Students at SD Negeri 37 Pekanbaru]. Jurnal PAJAR (Pendidikan dan Pengajaran), 3, 313-318.

Mulyasa. (2013). Pengembangan dan Implementasi Kurikulum 2013 [2013 Curriculum Development and Implementation]. Bandung: PT Remaja Rosdakarya Offset.

Paramita, N.M.A.S. (2019). Pengaruh Model Pembelajaran Picture and Picture Berorientasi Pendidikan Karakter terhadap Motivasi Belajar IPS Siswa Kelas $\mathrm{V}$ [The Effect of Picture and Picture Learning Model Oriented Character Education on Social Studies Learning Motivation of Class V . Students]. Journal of Education Technology, 3 (87), 1-8.

Prasetyo, E., Widyawati, S., Masyikur, R., \& Putra, F.G. (2018). Pengaruh Pembelajaran Picture and Picture ( PaP ) terhadap Hasil Belajar Matematika 
ditinjau dari Kecerdasan Spasial [The Effect of Picture and Picture Learning (PaP) on Mathematics Learning Outcomes in terms of Spatial Intelligence]. 11 (1), 50-61.

Shoimin, A. (2014). Model Pembelajaran Inovatif dalam Kurikulum 2013 [Innovative Learning Models in the 2013 Curriculum]. Yogyakarta: Ar-Ruzz Media.

Suroyya, H. (2018). Meningkatkan Hasil Belajar Geografi melalui Model Picture and Picture di MAN 3 Jakarta [Improving Geography Learning Outcomes through Picture and Picture Models at MAN 3 Jakarta]. Jurnal Kesejahteraan Keluarga dan Pendidikan. doi.org/10.21009/JKKP.022.02.

Trianto. (2010). Model Pembelajaran Terpadu [Integrated Learning Model]. Jakarta: Bumi Aksara. 